\title{
GEOMORPHOLOGY OF THE GOR GARANG GLACIERS, HIMACHAL PRADESH, INDIA*
}

\author{
By M. K. Kaul, A. R. Sharma, and D. N. Bhattacharya \\ (Glaciology Division, Geological Survey of India, Lucknow, India)
}

\begin{abstract}
A BSTRACT. The Gor Garang group of glaciers constitute an ice cover of over $4 \mathrm{~km}^{2}$ in a basin of $27 \mathrm{~km}^{2}$ area, lying in the Sutlej River catchment of the north-western Himalaya. This paper, the first record of these glaciers, their moraines and lakes observed in this area, is the result of mapping the glaciers and the pro-glacial field.

An attempt has been made to utilize lichenometry for establishing relative antiquity of various terminal moraine ridges generated by these glaciers, and six groups have been determined.
\end{abstract}

RÉsumé. Géomorphologie des glaciers de Gor Garang, Himachal Pradesh, Inde. Le groupe de glaciers de Gor Garang constitue une surface englacée de plus de $4 \mathrm{~km}^{2}$ dans un bassin versant de $27 \mathrm{~km}^{2}$, tributaire de la Sutlej River dans le Nord Ouest de l'Himalaya. Le présent article est le premier rapport sur ces glaciers, leur moraines et les lacs repérés dans cette zone et résulte de la cartographie de ces glaciers et de leur zone proglaciaire.

On a essayé d'utiliser la lichénométrie pour établir la chronologie relative des différentes ondulations morainiques engendrées par ces glaciers, et six stades ont été repérés.

Zusammenfassung. Geomorphologie der Gor Garang-Gletscher, Himachal Pradesh, Indien. Die Gletschergruppe Gor Garang, gelegen im Einzugsgebiet des Sutlej River im nordwestlichen Himalaya, bildet einen Eismantel von mehr als $4 \mathrm{~km}^{2}$ in einem Becken von $27 \mathrm{~km}^{2}$ Fläche. Der vorliegende Beitrag ist der erste Bericht über diese Gletscher, ihre Moränen und Seen, die in diesem Gebiet zu finden sind; er ist das Ergebnis einer Kartierung der Gletscher und ihrer Vorfelder.

Es wurde versucht, zur relativen Altersbestimmung verschiedener Endmoränenrücken die Lichenometrie heranzuziehen, und es gelang, damit sechs Altersgruppen festzustellen.

\section{INTRODUCTION}

Gor Garang nala is a tributary of the Baspa River, which in turn is a fifth-order tributary to the Sutlej River, in the Kinnaur District of Himachal Pradesh, India (Fig. 1). The Sutlej is a fourth-order basin in this part of the Himalaya, in accordance with the glacier-inventory norms (see Müller, 1978). The Gor Garang glacier basin, with its axis trending north-east-south-west, occupies rugged mountainous country in the main Himalayan range, covering an area of about $27 \mathrm{~km}^{2}$, of which $4 \mathrm{~km}^{2}$ are ice-covered in the form of five glaciers. The lowest limit of the basin is at about $3000 \mathrm{~m}$ near the confluence of Gor Garang nala with the Baspa River, while higher up it reaches an altitude of $6080 \mathrm{~m}$. This glacier basin is being studied as part of the International Hydrological Programme.

\section{Gor Garang GLaciers}

The glaciers in the Gor Garang basin have been named in a clockwise direction as Gor Garang glacier I to V (Fig. 2). The largest ice body is Gor Garang glacier I with an area of $2.02 \mathrm{~km}^{2}$, forming about $50 \%$ of the ice cover in the basin. The remaining ice cover is distributed between the other four ice bodies, which drain in a transverse direction to Gor Garang glacier I but have independent snouts.

\section{Gor Garang glacier I}

The snout of this glacier has a sinuous outline and is about $150 \mathrm{~m}$ wide. The glacial stream emerging from its melt-water outlet braids into smaller channels further down-stream. The glacier ice appears to be decaying fast at the snout. The melt-water outlet has an altitude of

* Published with the permission of the Director General, Geological Survey of India. 


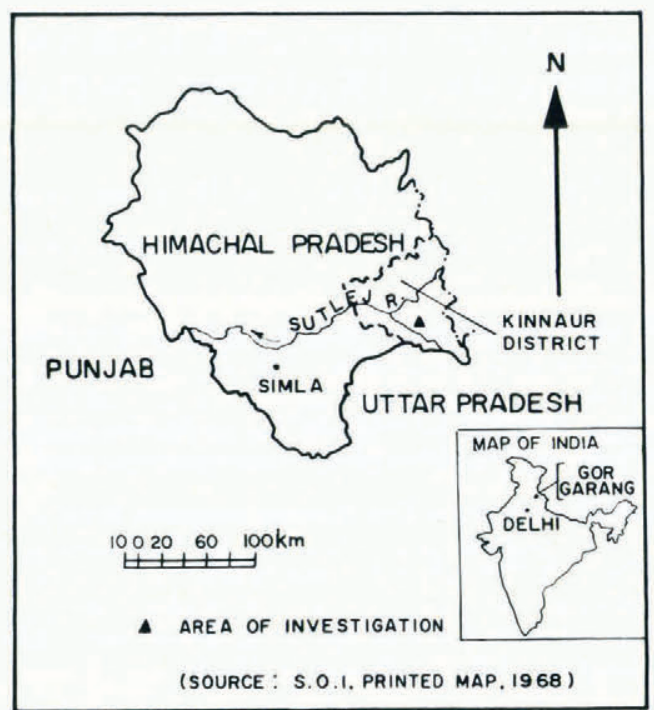

Fig. 1. Location of the Gor Garang glaciers, Himachal Pradesh, India.

$4760 \mathrm{~m}$ a.s.l. The geometry of this glacier is peculiar; although it has a broad ice field, its width suddenly decreases from about $1700 \mathrm{~m}$ to about $550 \mathrm{~m}$ immediately down-stream of the ice field, and thereafter it very gradually narrows down to its tongue. This sudden constriction is due to a rock ledge about $1000 \mathrm{~m}$ long and transverse to the glacier, which at present flows around the rock ledge. This is now exposed and is free of ice, although the glacier ice sometimes spills over the ledge and its accumulation is seen at the base of the ledge.

There are two prominent and steep ice aprons at the head of the glacier above the bergschrund, which is partly concealed by snow-avalanche chutes.

\section{Gor Garang glacier II}

The glacier snout, about $280 \mathrm{~m}$ wide, is well defined. The northern margin is covered by ablation moraines while the southern ice margin is exposed. The glacier is composed of two ice streams having independent ogives, and separated by a small medial moraine ridge (Fig. 3 ). The melt-water stream feeds a lake and thereafter it disappears, seeping into the moraine. The height of the melt-water outlet is $4798 \mathrm{~m}$ a.s.l.

\section{Gor Garang glacier III}

The snout of this glacier, which is only about $60 \mathrm{~m}$ wide, is completely obscured by the moraines. The melt-water outlet opens into a lake, which is filled by a subglacial stream, and has an altitude of $4845 \mathrm{~m}$ a.s.l.

\section{Gor Garang glacier IV}

This glacier has two melt-water outlets at altitudes of 4714 and $4675 \mathrm{~m}$ a.s.l. Ablation moraines completely cover the snout of the glacier, which terminates in a triangular tip. There are a few dead-ice blocks in the vicinity of the snout, left there by the glacier during its retreat and now protected by a moraine cover. 


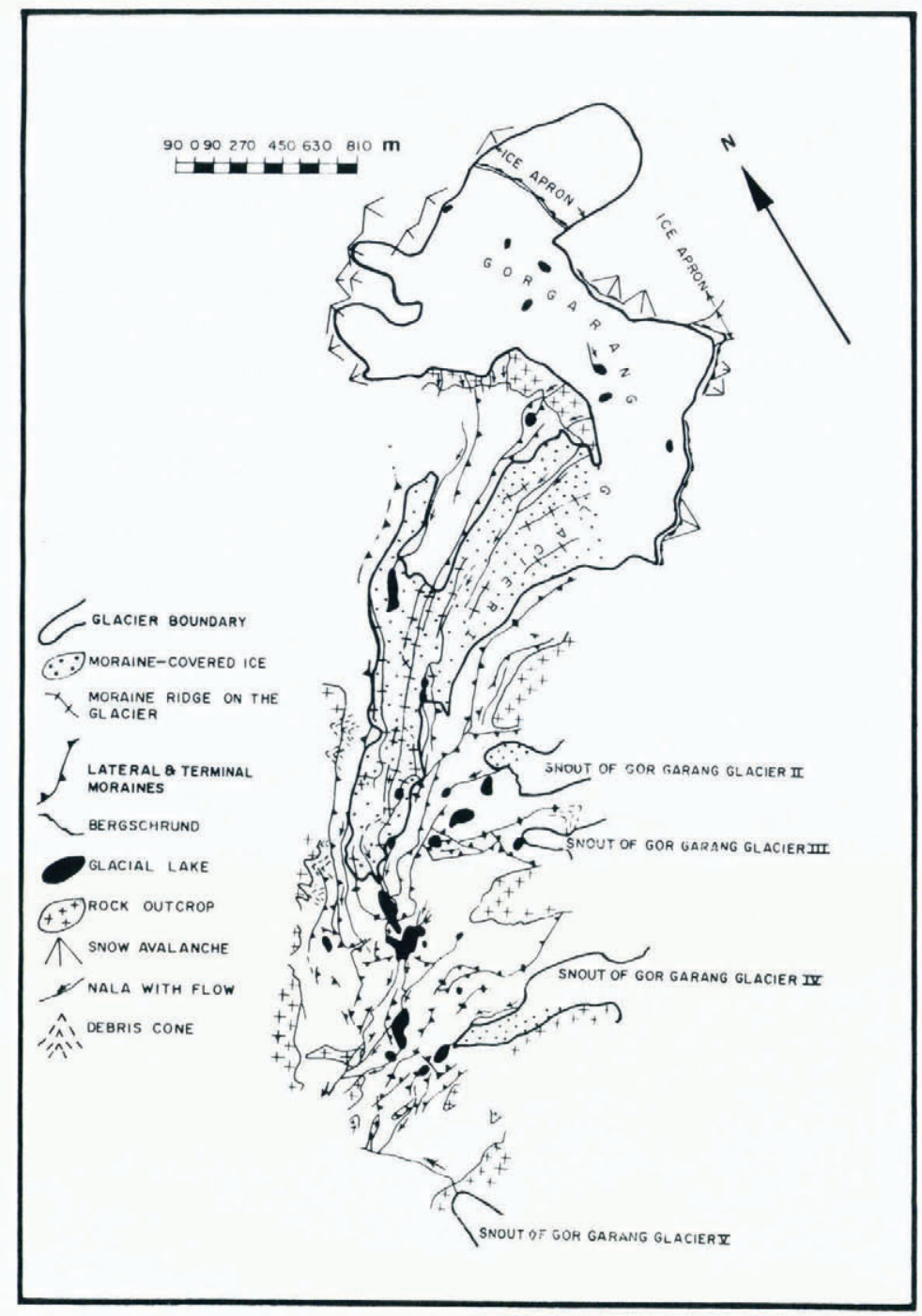

Fig. 2. Geomorphological features of the Gor Garang glaciers.

\section{Gor Garang glacier V}

This is a hanging glacier perched on a steep rock face. Water from its melt-water channel cascades down the cliff and blocks of ice together with englacial boulders are often seen falling down the cliffs. Its snout has a width of about $100 \mathrm{~m}$.

\section{Moraines}

The Gor Garang glacier basin belongs to a type which generates considerable volumes of rock debris.

Apart from the large amount of morainic debris alongside the valley walls and in the proglacial areas, the ice bodies themselves are profusely covered by a blanket of superficial moraine. 


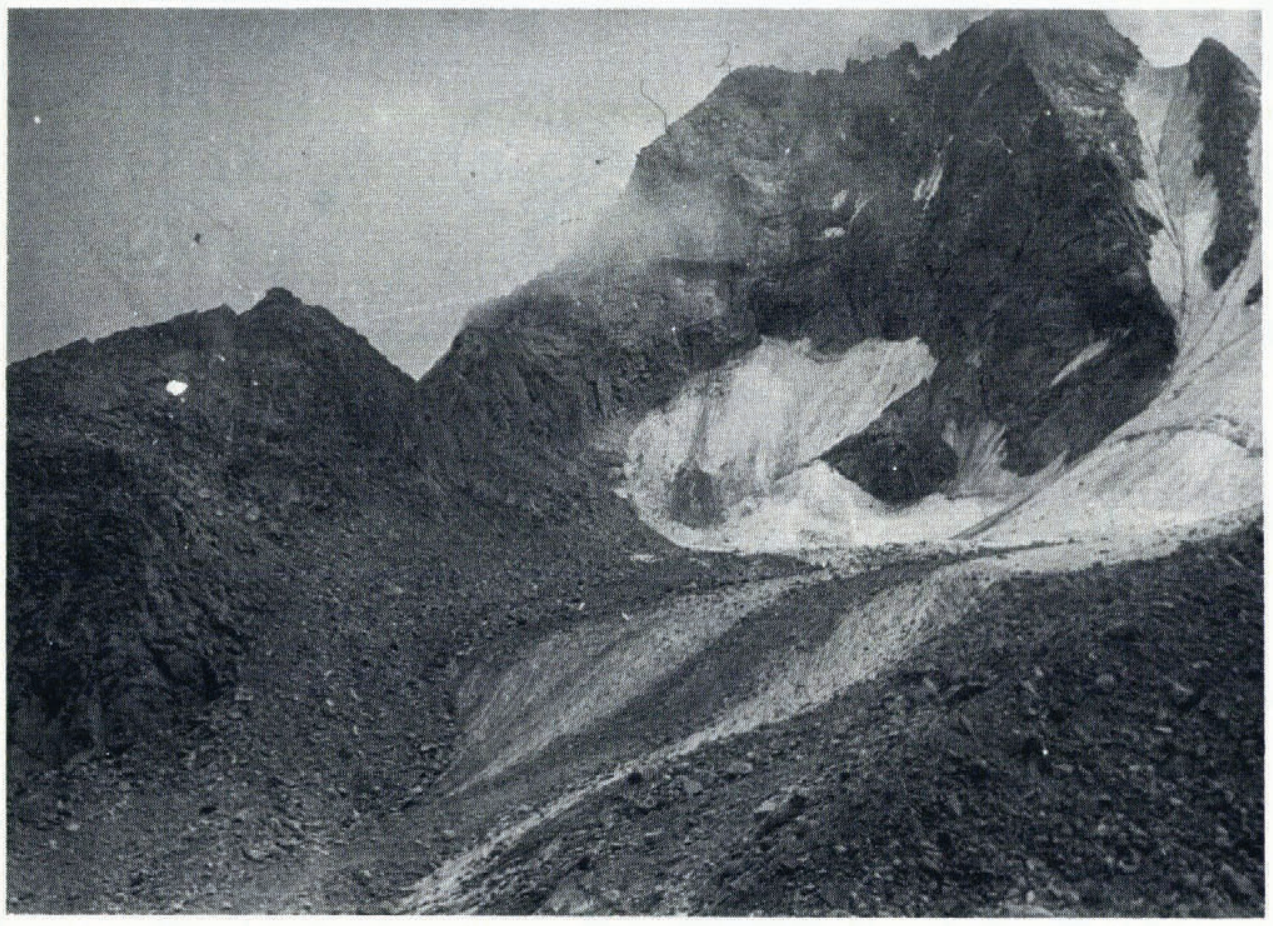

Fig. 3. Medial moraine ridge developing on Gor Garang glacier II.

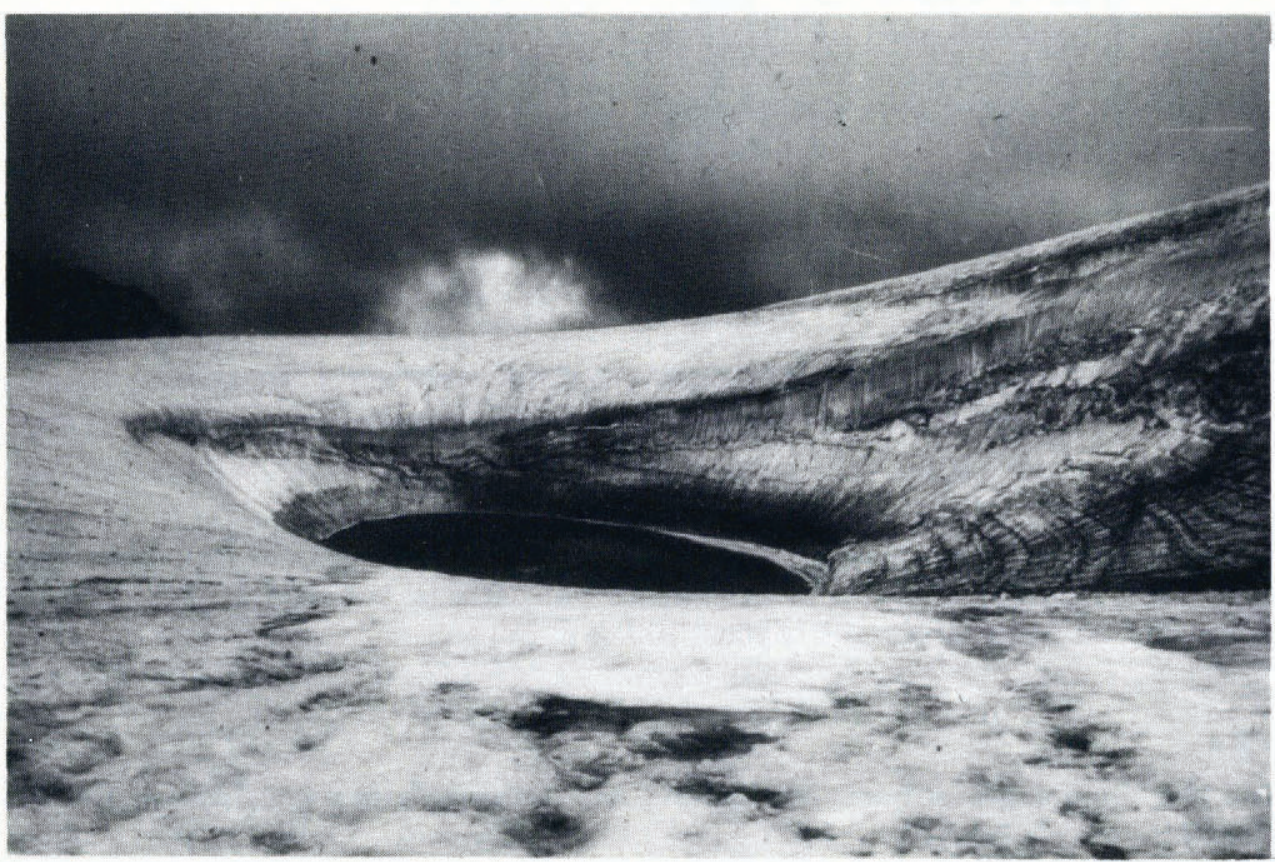

Fig. 4. An active supraglacial lake formed on glacier ice. 
This is especially true of Gor Garang glacier I, where $60 \%$ of its area is obscured by these moraines. The moraines have been classified into two types: "active moraines", which exist on the glacier surface and move with it, and "inactive moraines", which are static and exist only in the extra-glacial area.

\section{Active moraines}

All of the morainic material has been supplied to the glacier by mechanical weathering and frost shattering from the valley walls, including the accumulation area and the cirque region. This material falls directly on to the glacier surface in the ablation area and has also accumulated there as a result of ablation of the ice body.

The debris mass is gradually transported over the ice surface by two distinct processes: by flow of the glacier as a whole and by movement of boulders from one point to another on ice tables; in the latter case the movement is boulder by boulder. A certain thickness of morainic debris is required to prevent effectively the underlying ice from melting, which is satisfactorily provided by the debris cover present. This results in the formation of ridges that are relatively higher than the surrounding glacial surface. On the Gor Garang glaciers these ridges are of three types. The "lateral ridges" occupy the margins of the glacier; the "medial ridges" are aligned along the medial zone of the glacier and probably demarcate the main streams of ice flow. Both of these types show curves of varying amplitudes matching with the general trend of the glacier flow. In addition to these ridges, there are smaller "transverse ridges" lying across the general trend.

\section{Inactive moraines}

These are confined exclusively to the extra-glacial areas and girdle the ice bodies in the form of lateral and terminal moraines. The lateral moraines of all these glaciers consist of a succession of sinuous ridges which can be assigned to their respective glaciers. The difference in the number of lateral moraine ridges from one glacier to another may reflect differences in the manner of retreat of the various glaciers over time.

At least seven undoubted terminal moraine ridges have been recognized in the Gor Garang basin. In addition, small humps with no specific orientation are strewn all over the pro-glacial area. Only one terminal moraine ridge seems to represent the recessional phase when all these glaciers might have been joined together. Other ridges can be assigned to their respective glaciers. These terminal moraines are therefore independently related to the recessional phases of their respective glaciers. The moraines of these glaciers consist of assorted boulders of granite, basic rocks, rock flour, and sand particles.

\section{Glacial LaKes}

One of the most interesting features of the Gor Garang group of glaciers is the existence of numerous small lakes. Apart from their varied distribution in the glacial and pro-glacial areas, some of them also show variations in time. Depending on their location and nature of occurrence, these have been classified as follows.

\section{Active supraglacial lakes}

These are restricted to the glacier surface and are located entirely within the ice (Fig. 4). They are large placid pools of water into which ice melt percolates from the lake walls or from small rills on the glacier surface. The lake water is perennial and has no visible outlet. The lakes are circular or oblong in outline and their depths vary from 5 to $15 \mathrm{~m}$. There are two essential peculiarities of these lakes: they are always water-filled and have been enlarging their size during the period of observation. 


\section{Former supraglacial lakes}

These depressions were once water-filled but are now devoid of it; there is evidence of the water having drained from them. Glacier ice forms the lake walls and at the bottom ground moraine is exposed as a result of complete melting of the ice. Narrow channels wind their way across the assorted boulders of the ground moraine and the dissected mounds of finer sediments at the lake bottom. Small pools of water or small depressions represent the remnants of these dried-up lakes.

\section{Stable pro-glacial lakes}

The lakes of the pro-glacial area that regularly receive supplies of water and are perennial

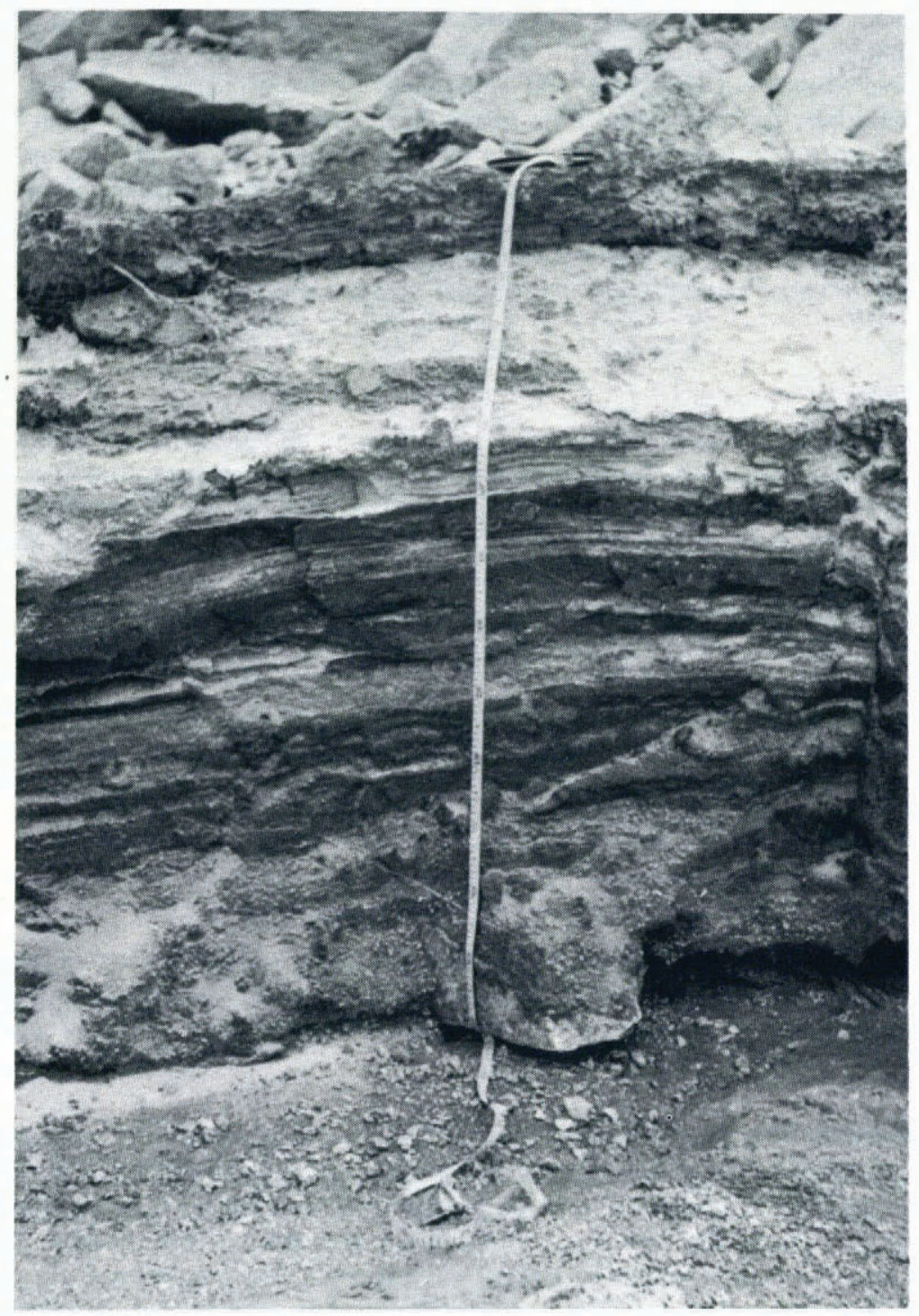

Fig. 5. Sediments in a former lake depression at an altitude of $4790 \mathrm{~m}$ in the Gor Garang basin. 
water bodies are included here. These lakes may either have inlet and outlet channels on the surface or water may infiltrate into the underlying moraine from the bottom of the lake. Finer sediments are deposited on the lake bottom. At the periphery of some of these lakes at an altitude of $4790 \mathrm{~m}$ interesting bedded sediments were recorded (Fig. 5). The deposit, which is about $0.80 \mathrm{~m}$ thick, has 17 alternating light and dark bands. The light-coloured bands range in thickness from 1 to $10 \mathrm{~cm}$, while the darker bands vary from 2 to $8 \mathrm{~cm}$. The darker bands are clayey whereas the lighter bands are sandy. Sedimentary structures simulating convolution and slumping were also observed in this deposit.

\section{Unstable pro-glacial lakes}

In the pro-glacial area of the Gor Garang group of glaciers, small water bodies have been noticed which may either gradually dry up or disappear suddenly. Their behaviour is unpredictable. The source of the water is either transitory, in the form of winter snow which gradually melts away, or the water may suddenly disappear due to the re-opening of a blocked outlet. These lakes invariably leave testimony of their former existence in the form of a circular mark at the last high-water level.

Another lake type is now represented by small sandy flats which occupy the sites of dammed up reservoirs, formed by avalanche fans or moraine deposition.

\section{LICHENOMETRY}

The technique of dating neoglacial deposits by the study of lichens growing on them has been used recently in different parts of the world. The basic principle is that colonization by lichens begins after the deposit has been exposed and relieved of ice; the rate of growth of a lichen thallus is directly proportional to the time of its exposure. The greater the diameter of the lichen

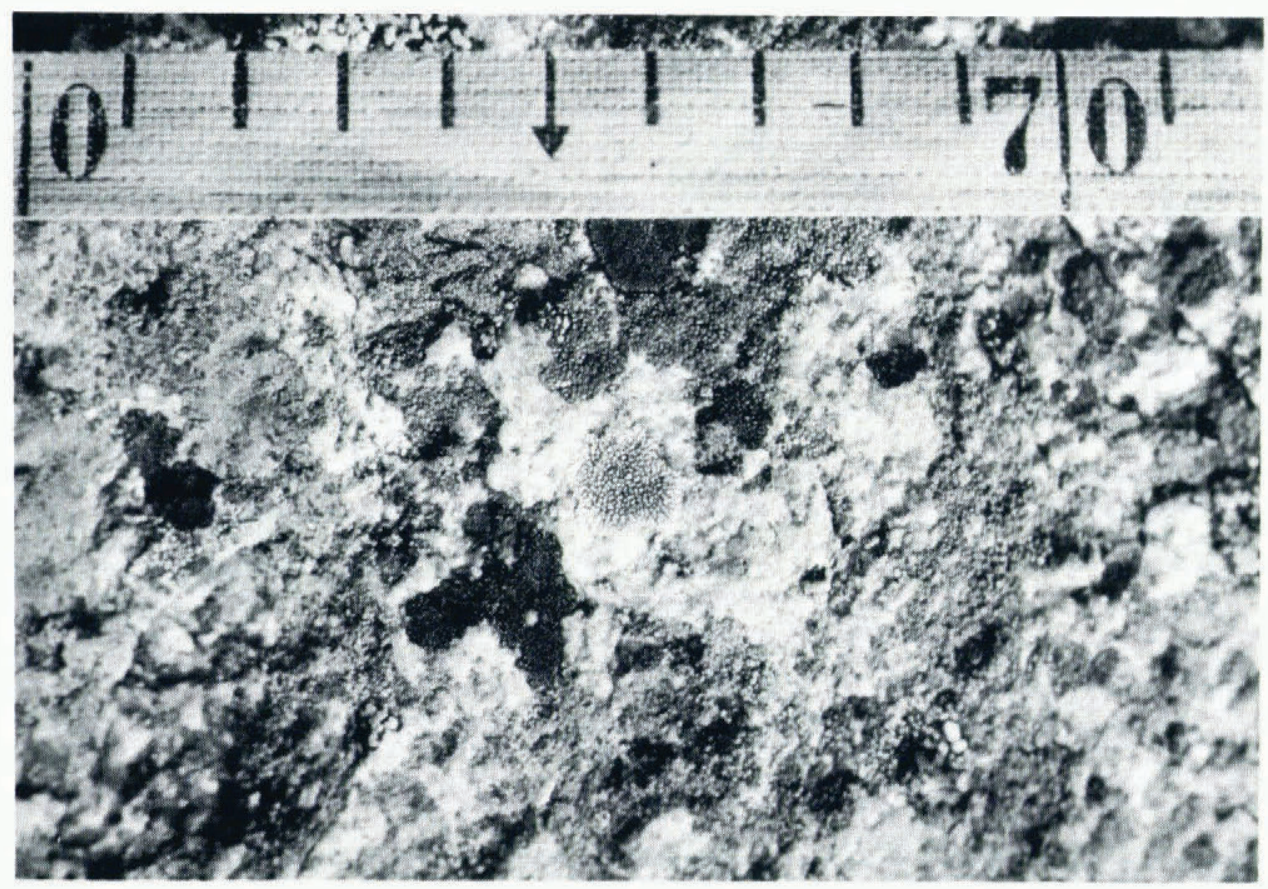

Fig. 6. Lichen growth on one of the terminal moraines. The scale is in centimetres. 
thallus, the greater is the relative age of the substrate on which it grows. Studies of lichens have been in progress in some of the glacier areas in the Himalaya since 1976.

Such studies have been carried out on the terminal moraines (Fig. 6) of the Gor Garang group of glaciers for the first time. This study included statistical sampling of the thallus diameters of various common lichen species on all the terminal moraines and comparison of the largest thallus diameter for an individual species from each moraine ridge. Seven prominent terminal moraines in the frontal zones of the glaciers were sampled. In all these terminal moraine ridges about 1500 observations on lichen diameters were recorded from 19 sampling sites each of $50 \mathrm{~m}^{2}$. The species whose diameters were recorded are Rhizocarpon sublucidum, Rhizocarpon macrosporam, Xanthoria elegans, Rinodina oriena, and Acrospora assimulans Vain. Of these, $R$. sublucidum, $R$. macrosporam, and $A$. assimulans Vain. were relatively abundant.

For the estimation of the growth rate of a species, it is necessary to have a reference of known age for absolute age determination. Since this work is the first of its kind in this area, no previous records are available. An attempt has therefore been made to estimate only the relative ages of the moraine ridges based on relative thallus diameters. The seven terminal moraine ridges have yielded six age groups, two of the ridges being of the same age according to the lichen diameters (Fig. 7).

Table I shows the maximum diameters of these species and the lichen cover as recognized on different terminal moraine ridges.

Although some of these values are not significantly different, they provide some clue to the relative antiquity of the moraine ridges. It appears that stage $\mathrm{I}$ is significantly older than the others and it represents an older stage when all of the Gor Garang glaciers were confluent.

The results obtained showed consistency for only three species, i.e. $R$. sublucidum, $R$. macrosporam, and A. assimulans Vain. However, it should be noted that in the case of

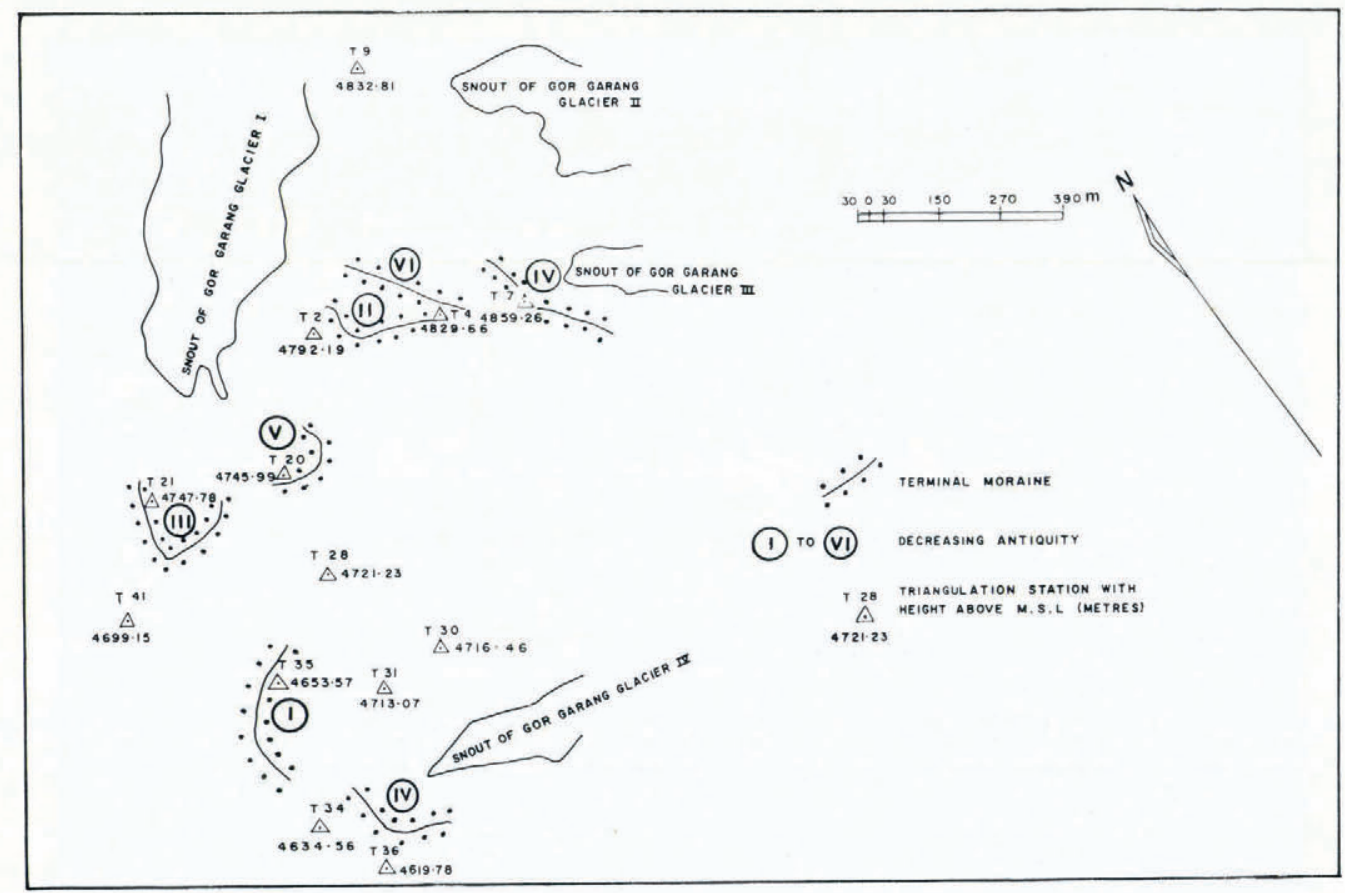

Fig. 7. Relative antiquity of the terminal moraines of the Gor Garang group of glaciers interpreted from lichenometry. 
TABLE I

\section{Species}

Rhizocarpon sublucidum Rhizocarpon macrosporam Acarospora assimulans Vain.

Percentage lichen cover

Maximum thallus diameter $(\mathrm{mm}$ ) on terminal moraines in order

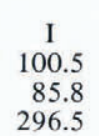

296.5

90 of decreasing antiquity

\begin{tabular}{cclll} 
II & III & IV & \multicolumn{1}{c}{ V } & VI \\
43.4 & 41 & 38 & 32 & 27 \\
45.5 & 32.5 & 28 & 23 & 20 \\
201.5 & 108 & 86.5 & 78.5 & 67.5 \\
70 & 60 & 50 & 40 & 20
\end{tabular}

A. assimulans Vain. there is a significant difference in the values obtained. The remaining species showed inconsistent values.

\section{ACKNOWLEDGEMENTS}

The authors are grateful to Mr C. P. Vohra, Director, Glaciology Division, Geological Survey of India, for providing an opportunity for these studies and for his guidance throughout the course of the investigation. We also acknowledge the benefit derived from discussions with him about this work. The authors are grateful to Dr D. D. Awasthi of the Botany Department, Lucknow University, for specific identification of the lichens.

MS. received 22 January 1980 and in revised form 6 August 1980

\section{REFERENCE}

Müller, F. 1978. Temporary Technical Secretariat for World Glacier Inventory, International Commission on Snow and Ice. Instructions for compilation and assemblage of data for a world glacier inventory. Supplement: identification/glacier number. Zürich, Dept. of Geography, Swiss Federal Institute of Technology (ETH). 